\title{
Towards an Integrative Model of Sources of Personality Stability and Change
}

\author{
Jenny Wagner, University of Hamburg, Germany \\ Ulrich Orth, University of Bern, Switzerland \\ Wiebke Bleidorn, University of California, Davis, United States \\ Christopher J. Hopwood, University of California, Davis, United States \\ Christian Kandler, University of Bremen, Germany
}

Word count: 2497 (2500 max)

2020-03-26

This is an unedited manuscript accepted for publication at Current Directions in Psychological

Science. The manuscript will undergo copyediting, typesetting, and review of resulting proof before it is published in its final form.

Corresponding author: Jenny Wagner, Van-Melle-Park 5, 20146 Hamburg, Germany, phone. +49 40 42838-5485, fax: +49 40 42838-5486, e-mail: jenny.wagner@uni-hamburg.de 


\begin{abstract}
There is now compelling evidence that people's typical patterns of thinking, feeling, striving, and behaving are both consistent and malleable. Therefore, researchers have begun to examine the distinct sources of personality stability and change. In this article, we discuss traditional classifications of sources, review key findings, and highlight limitations and open questions in research on personality stability and change. We conclude by describing an integrative model and by outlining important directions for future research.
\end{abstract}

Keywords: personality stability and change; genetic and environmental sources; person and situation; integrative model 


\section{Towards an Integrative Model on Sources of Personality Stability and Change}

The major mission of personality psychology is to describe and explain individual differences in people's typical thinking, feeling, striving, and behaving. Despite ongoing debates about which characteristics should be subsumed under the umbrella term personality, recent work has converged upon general agreement about the necessity for a limited number of constructs to economically describe interindividual differences in key characteristics (Kandler et al., 2014). Two further milestones characterize recent progress in the field of personality psychology: First, research has established that personality differences predict major life outcomes such as educational achievement, work success, health, well-being, and even mortality (Soto, 2019). Second, the traditional view that adult personality traits are completely stable has been dismissed (Bleidorn et al., 2019). A compelling body of evidence shows that personality traits are characterized by both stability and change across the entire lifespan. This appears to be true with respect to rank-order, mean-level, and individual-level stability and change (Lucas \& Donnellan, 2011; Wagner et al., 2019). These insights naturally lead to the broad question: Why do personality traits change or remain stable?

Over the past two decades, a large number of methodologically sophisticated studies using longitudinal twin, cross-sequential panel, and dynamic daily-diary designs have focused on the examination of various sources of personality stability and change. Irrespective of the particular study design or trait measure, evidence has been mixed and researchers have not yet come to convincing conclusions about the sources that underlie personality trait change. To move forward, research on the sources of personality stability and change needs to become more integrative and dynamic. To illustrate, we first describe two traditional classifications of sources of personality stability and change, and argue that an integrative scheme is needed to resolve current challenges related to traditional classifications. We then review established knowledge, equivocal findings, and blind spots in the literature on the sources of stability and change. Finally, we make a case for an evidence-based model that integrates multiple relevant 
sources that likely interact in synergetic and dynamic ways and provide specific recommendations for future research based on this model.

\section{WHAT ARE SOURCES?}

There are at least two established classifications of sources of personality stability and change. The first involves the traditional differentiation between genetic and environmental sources. Behavioral genetic studies have provided evidence that both genes and life experiences are involved in both stability and change (Bleidorn et al., 2014). Although the interdependence of these two sources is well-established (e.g., Plomin et al., 1977), empirical evidence for the interplay has been limited due to limitations of data, designs, and methods. More recently, researchers have used improved epigenetic and behavioral genetic approaches that illustrate that genetic sources are interwoven with environmental factors in various ways on the pathway from genetic differences via biological differences to personality differences. For example, environmental factors can alter genetic activity and shape gene expression without changing genes (i.e., environmental epigenetic regulation; Shah et al., 2014). Likewise, the effects of life experiences can depend on an individual's genetic sensitivity to those influences (Byrd \& Manuck, 2014).

The second traditional approach to classifying sources involves the differentiation between personal and situational/contextual (re)sources and how they interact and covary with each other (Rauthmann et al., 2015). However, two facts blur the distinction between the person and the environment. First, personality is clearly "contextualized/situational" in nature, as implied by its definition and measurement (Roberts, 2009). For example, extraverts are well aware of the fact that extraverted behavior is more appropriate at a party and less so at a funeral. Second, "personal" sources add the feature of self-concept and self-regulatory processes to the classification scheme. People set goals, follow needs, strive for enhancement, select or avoid situations and manipulate or create environmental conditions - thus, people are often agents of their own stability and change (Hennecke et al., 2014). That is, although 
people cannot change their genetic makeup by choice, other personal and environmental sources are subject to individual control. For example, research on volitional personality change shows that people who want to change specific aspects of their personality can develop in the direction of their desired trait levels (Hudson \& Fraley, 2017). Accordingly, the person(ality) itself reflects a source of its own stability and change, as individuals select themselves into environments (e.g., through choice of a profession and workplace) and alter their behavioral styles to better fit into the environment (e.g., through becoming more reliable and organized at the workplace).

Despite the longstanding recognition that sources of personality stability and change interact and covary, empirical research has largely been limited to the dichotomies of these two classifications. From an integrative perspective, it is important to bear in mind that selfregulation is not independent from genetic predisposition and environmental sources but involves both (Mischel, 2004). Consistent with the person(ality)-environment fit approach (Scarr \& McCartney, 1983), genetic differences in personality traits may affect the individuals' experiences of events and self-determined exposures to certain environments that may, in turn, affect the stability and change in those or other personality characteristics. In other words, innate differences can guide people to have differential experiences that in turn shape personality differences. As a consequence, each personal or contextual (re)source of personality stability and change will to some degree reflect both genetic and environmental causation (Briley et al., 2018) as well as personal and situational factors. This complex interdependence highlights a major limitation of traditional classifications that attempted to sort sources into distinct categories of genetic versus environmental or personal versus situational/contextual sources. It calls for integration.

\section{WHAT DO WE KNOW?}

Despite many efforts, research has yet been unable to identify one particular gene, event, or situational/contextual circumstance that is a strong, replicable source of personality 
stability and change. For example, despite large-scale genome-wide associations studies, effect sizes of any single genetic variant are generally very small and do not account for substantial proportions of variance in personality traits (de Moor et al., 2012). Because the genetic unfolding depends on environmental opportunities, the same genetic variant can result in different phenotypes, and different constellations of genes can produce the same phenotypic expression. This reduces the probability of robust main effects of single genes on personality traits.

Analogously, the main effects of specific life experiences on personality trait change are very small (Bleidorn et al., 2018). Nevertheless, there are some robust effects of life events on personality change, which can be sorted into three major domains: work, love, and health. With regard to work, the transition from high school to college, university, or vocational training is associated with substantial normative increases in emotional stability, agreeableness, and conscientiousness (Lüdtke et al., 2011). Moreover, work and career investments can lead to increases in agreeableness and conscientiousness (Hudson \& Roberts, 2016). However, the evidence is less robust regarding several other work-related factors such as the transition into the first job (Deventer et al., 2019) or retirement (Schwaba \& Bleidorn, 2018). Even less is known about conditions of developmental paths within the working context such as transactional processes between work-role demands and personality change across the adult lifespan (Denissen et al., 2013). Finally, we know almost nothing about the influence of contextual work characteristics (e.g., occupational prestige of someone's job, income), or psychological work characteristics (e.g., autonomy, role complexity) on personality stability and change.

In the domain of love, a robust finding is the increase in emotional stability, extraversion, and self-esteem following the transition to the first romantic relationship (Luciano \& Orth, 2017; Wagner, et al., 2015). A second robust finding is that the experience of social inclusion can contribute to increases in self-esteem (Harris \& Orth, 2019; Hutteman 
et al., 2015). With regard to many other relationship transitions and characteristics, however, evidence is limited (Bleidorn et al., 2018). Finally, we know very little about the influence of family relationships during childhood on long-term personality development, including whether these early relationships have an enduring effect on personality that can still be observed in adulthood (for an example, see Orth, 2018).

Changes in the health domain are regarded as influential sources of personality stability and change, especially in late adulthood (Wagner \& Mueller, 2017). Specifically, terminal declines across multiple facets of health, including cognitive, physical, and sensory functioning, can challenge older people's ability to maintain their everyday routines and lifestyle. Accordingly, there are robust findings on reverse trends in maturity-related traits which may not be linked with negative consequences late in life, but rather reflect developmental adaptations that help individuals to adjust their daily experiences and behavior in accordance with existing resources (Kandler et al., 2015; Mueller et al., 2018). In contrast, the effects of non-normative health-related events on personality changes, such as accidentrelated injuries or enduring health consequences, are less consistent. Although initial evidence associated the sheer number and onset of specific chronic diseases (e.g., stroke) with personality change, evidence for robust accident-related personality differences at a population level is weak. Finally, how normative and non-normative health-related experiences and changes interact with further person(ality) and environmental (re)sources has yet to be examined.

\section{WHERE DO WE GO FROM HERE?}

The predominant focus on distinctive sources of personality stability and change in theory and research has contributed to relatively few robust findings. Although it is generally established that seemingly different sources of personality stability and change do not operate independently of each other but may interact in complex ways, it is still an open and pressing question: In what ways can different sources be integrated both theoretically and in research 
designs to examine their unique and joint effects on differential personality stability and change? To begin to address this question, we propose an evidence-based model that integrates various sources that might interact and transact synergistically and dynamically. Such a model needs to integrate both personal and environmental sources.

Figure 1 shows a simplistic scheme illustrating this kind of integrative model. This model proposes that the person can be characterized by means of more or less stable characteristics that give rise to individual differences in thoughts, feelings, strivings, and behaviors. An individual's genetic makeup can be expressed via both relatively stable traits and momentary states. Through related cognitions, emotions, motivations, and behavior, genes can influence sources outside the person and thus guide the person through environmental conditions. The environment reflects different external circumstances, which can also be regarded as more or less stable contexts and short-term situational fluctuations. Environmental influences interact and transact both with each other and with internal sources. Within external sources, cultural contexts might differentially exert pressure on social roles (e.g., parent or spouse) and thus affect the specific realization of relationships (e.g., among spouses) as well as daily tasks (e.g., sharing of daily chores). To illustrate the expected complex interplay between sources, one could expect that affective states, motives, or trait levels of a person mold the experience of social roles, the realization of relationships, or the dealing with specific situations. The environment, in turn, provides opportunities and limits that reinforce or change person(ality) characteristics.

We propose that a comprehensive understanding of the factors that underlie personality stability and change requires an integration of various of these sources that may be correlated and interact with each other. 


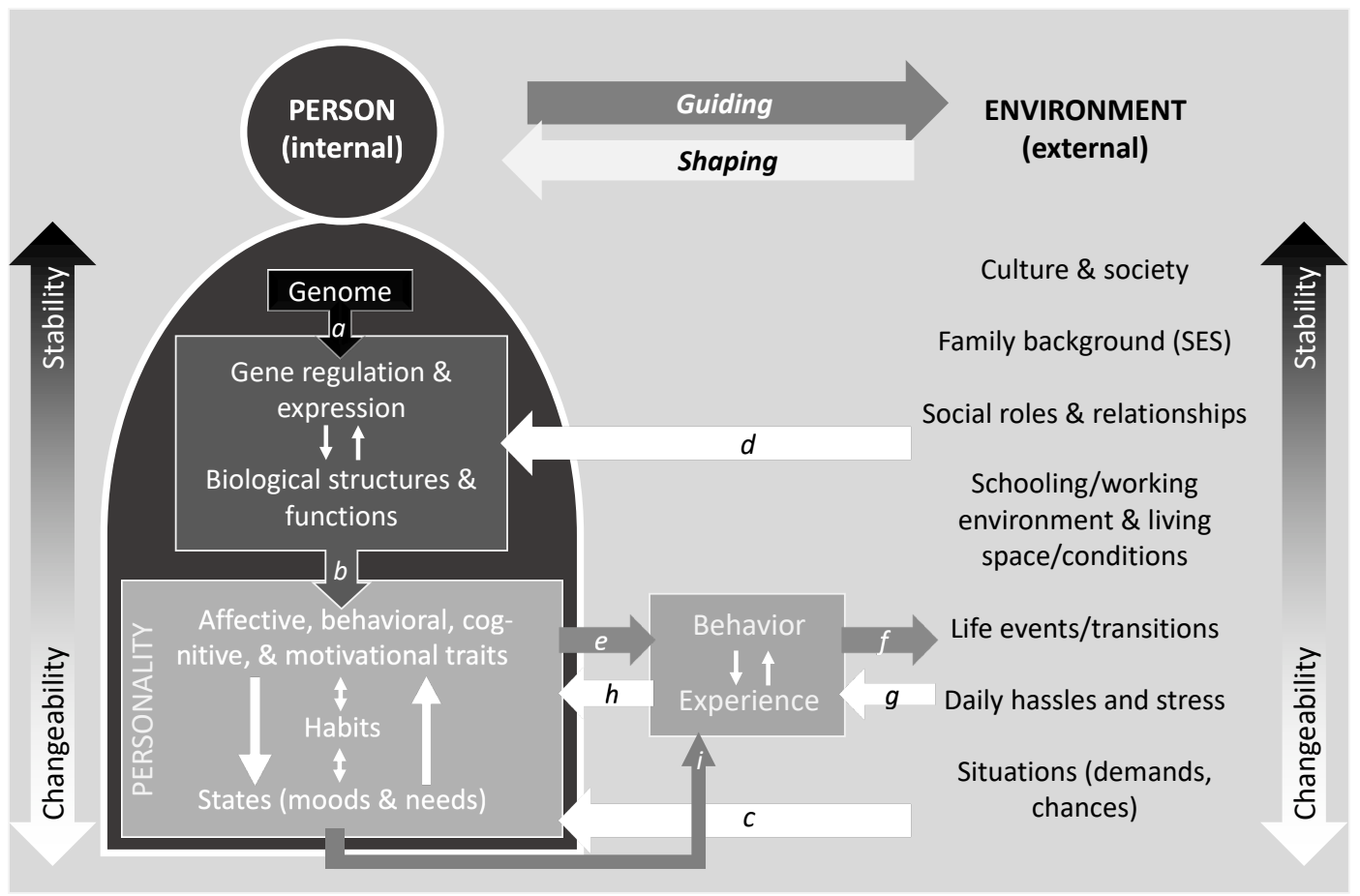

Figure 1. Integrative source model illustrating the complex interplay between and within personal and environmental (re)sources giving rise to the stabilization and changeability of personality characteristics. Arrows represent directional relationships between variables. Stable genetic differences unfold their influences on personality variation indirectly via largely stable individual differences in gene expression, protein synthesis, morphological structures, nervous and endocrine systems, and their functions $(f[a, b])$. Environments provide more or less stable (cultural, social, and physical) opportunities and limits for personality unfolding (c). Environments (e.g., chronic stress) can influence neural and hormonal activity as well as gene regulation and expression $(d)$. Personality differences can influence the environment $(f[e, f])$ and so can genetic differences $(f[a, b, e, f])$ via characteristic patterns of behavior, which reflect the individual expression of personality characteristics in a situation $(e)$ and increase the probability of exposure to specific environments $(f)$. Environmental factors also act through the filter of the individual construction of experiences $(f[g, h])$, which is more or less driven by personality characteristics $(i)$. 
We close this paper by outlining five recommendations for future research as well as further elaborations on the implications of such an integrative model.

Our first recommendation is for theory and research to consider the effects of multiple sources' interactions and transactions shaping individuals' personality. As an example of such a complex research approach, we refer to a study by Ge, Natsuaki, Neiderhiser, and Reiss (2009), which used a longitudinal genetically informed sibling design to disentangle diverse sources (e.g., genes, events, social relationships) and illustrated that increased mother-child closeness in early adolescence buffers the detrimental influence of negative life events on developmental trajectories of negative emotionality in late adolescence.

Second, given that a person's genetic sensitivity drives individual exposure and reactions to life experiences, future studies need to model this sensitivity. In an exemplary study accounting for gene-environment interplay, Kandler and Ostendorf (2016) found that genetic differences in proneness to depression among women were primarily mediated by individual differences in neuroticism and that a negative life-event balance (i.e., accumulation of negative experiences and absence of positive experiences) increased the risk of depression for women with a high level of neuroticism, but not for emotionally stable women.

Third, integrative research is needed to understand how diverse sources interact and unfold over time. For example, Mueller and colleagues (2020) used experience sampling data of older couples with an 18-months follow up to examine the degree to which the coupling of momentary affect in couples differed depending on their levels of neuroticism, and whether this spousal coupling of momentary affect contributed to differential changes in neuroticism 18 months later. Results illustrated stronger coupling in positive affect for individuals high in neuroticism and decreases in neuroticism over time in those participants who showed a higher degree of coupling with their partner's positive affect.

Fourth, most research on personality change is based on self-report measures. Because self-report data is heavily influenced by self-concepts and can thus depart from other types of 
data, differential stability and change in aspects of personality based on other forms of data is largely unknown. Although research using informant reports (e.g., from parents and peers) suggests comparable results on personality stability and change with respect to some traits (Göllner et al., 2017; Kandler et al., 2010), future studies on the interplay of sources and potential intervention studies should integrate diverse measures of personality.

Fifth, more attention should be paid to the processes and mechanisms at play. We see two broad avenues for taking future research in this direction. The first involves understanding the processes by which sources get under the skin and lead to actual personality change (Baumert et al., 2017). The second is examining the effect of interventions on certain personality characteristic in certain contextual conditions (Allemand \& Flückiger, 2017). Personality intervention research leads to a host of important practical questions, such as whether interventions in educational settings of adolescence and young adulthood are more or less effective during this highly dynamic time of personality development. Adolescence and young adulthood are characterized by a multitude of developmental tasks related to education, romantic relationships, identity formation, living conditions, and financial independence. These tasks do not necessarily occur in a fixed sequence but are interrelated and may interact to shape personality differences. Thus, interventions possibly buffer or amplify other changes, and their effects might additionally depend on personal (e.g., genetic sensitivity) and environmental (re)sources (e.g., social support).

In summary, the predominant focus on main effects of distinctive sources of personality stability and change has constrained progress in the field of personality development. Future research needs to account for the complex, dynamic, and synergetic ways in which person and environment transact in shaping personality differences. We propose an integrative perspective on how different sources cascade to influence people's personality development that leads to specific recommendations that we hope will guide future integrative research on the sources of personality stability and change. 


\section{References}

Allemand, M., \& Flückiger, C. (2017). Changing personality traits: Some considerations from psychotherapy process-outcome research for intervention efforts on intentional personality change. Journal of Psychotherapy Integration, 27(4), 476-494. https://doi.org/10.1037/int0000094

Baumert, A., Schmitt, M., Perugini, M., Johnson, W., Blum, G., Borkenau, P., Costantini, G., Denissen, J. J. A., Fleeson, W., Grafton, B., Jayawickreme, E., Kurzius, E., MacLeod, C., Miller, L. C., Read, S. J., Roberts, B., Robinson, M. D., Wood, D., \& Wrzus, C. (2017). Integrating Personality Structure, Personality Process, and Personality Development: Integrating personality. European Journal of Personality, 31(5), 503528. https://doi.org/10.1002/per.2115

Bleidorn, W., Hill, P., Back, M., Denissen, J. J. A., Hennecke, M., Hopwood, C. J., ... Roberts, B. (2019). The Policy Relevance of Personality Traits. American Psychologist, 74, 1056-1067. http://dx.doi.org/10.1037/amp0000503

Bleidorn, W., Hopwood, C. J., \& Lucas, R. E. (2018). Life events and personality trait change. Journal of Personality, 86, 83-96. http://dx.doi.org/10.1111/jopy.12286

Bleidorn, W. Kandler, C., \& Caspi, A. (2014). The behavioural genetics of personality development in adulthood—classic, contemporary, and future trends. European Journal of Personality, 28, 244-255. http://dx.doi.org/10.1002/per.1957

Briley, D. A., \& Livengood, J., \& Derringer, J. (2018). Behavior genetic frameworks of causal reasoning for personality psychology. European Journal of Personality, 32, 202-220. https://doi.org/10.1002/per.2153

Byrd, A. L., \& Manuck, S. B. (2014). MAOA, childhood maltreatment, and antisocial behavior: Meta-analysis of a gene-environment interaction. Biological Psychiatry, 75, 9-17. https://doi.org/10.1016/j.biopsych.2013.05.004 
de Moor, M. H. M., Costa, P. T., Terracciano, A., Krueger, R. F., de Geus, E. J. C., . . Boomsma, D. I. (2012). Meta-analysis of genome-wide association studies for personality. Molecular Psychiatry, 17, 337-349. https://doi.org/10.1038/mp.2010.128

Denissen, J. J. A., Ulferts, H., Lüdtke, O., Muck, P. M., \& Gerstorf, D. (2014). Longitudinal transactions between personality and occupational roles: A large and heterogeneous study of job beginners, stayers, and changers. Developmental Psychology, 50, 19311942. https://doi.org/10.1037/a0036994

Deventer, J., Lüdtke, O., Nagy, G., Retelsdorf, J., \& Wagner, J. (2019). Against all odds - is a more differentiated view of personality development in emerging adulthood needed? The case of young apprentices. British Journal of Psychology, 110, 60-86. https://doi.org/10.1111/bjop.12336

Ge, X., Natsuaki, M. N., Neiderhiser, J. M., \& Reiss, D. (2009). The longitudinal effects of stressful life events on adolescent depression are buffered by parent-child closeness. Development and Psychopathology, 21, 621-635.

http://dx.doi.org/10.1017/S0954579409000339

Göllner, R., Roberts, B. W., Damian, R. I., Lüdtke, O., Jonkmann, K., \& Trautwein, U. (2017). Whose "storm and stress" is it? Parent and child reports of personality development in the transition to early adolescence: Personality development in early adolescence. Journal of Personality, 85(3), 376-387. https://doi.org/10.1111/jopy.12246

Harris, M. A., \& Orth, U. (2019). The link between self-esteem and social relationships: A meta-analysis of longitudinal studies. Journal of Personality and Social Psychology. Advance online publication. http://dx.doi.org/10.1037/pspp0000265

Hennecke, M., Bleidorn, W., Denissen, J. J. A., \& Wood, D. (2014). A Three-Part Framework for Self-Regulated Personality Development across Adulthood. European Journal of Personality, 28, 289-299. https://doi.org/10.1002/per.1945 
Hudson, N. W., \& Fraley, R. C. (2017). Volitional personality change. In J. Specht (Ed.), Personality development across the lifespan (pp. 555-571). London, UK: Elsevier. http://dx.doi.org/10.1016/B978-0-12-804674-6.00033-8

Hutteman, R., Nestler, S., Wagner, J., Egloff, B., \& Back, M. D. (2015). Wherever I May Roam: Processes of Self-Esteem Development From Adolescence to Emerging Adulthood in the Context of International Student Exchange. Journal of Personality and Social Psychology, 108, 767-783. https://doi.org/10.1037/pspp0000015

Kandler, C., Bleidorn, W., Riemann, R., Spinath, F. M., Thiel, W., \& Angleitner, A. (2010). Sources of cumulative continuity in personality: A longitudinal multiple-rater twin study. Journal of Personality and Social Psychology, 98, 995-1008. http://dx.doi.org/10.1037/a0019558

Kandler, C., Kornadt, A. E., Hagemeyer, B., \& Neyer, F. J. (2015). Patterns and sources of personality development in old age. Journal of Personality and Social Psychology, 109, 175-191. http://dx.doi.org/10.1037/pspp0000028

Kandler, C., \& Ostendorf, F. (2016). Additive and synergetic contributions of neuroticism and life events to depression and anxiety in women. European Journal of Personality, 30, 390-405. http://dx.doi.org/10.1002/per.2065

Kandler, C., Zimmermann, J., \& McAdams, D. P. (2014). Core and surface characteristics for the description and theory of personality differences and development. European Journal of Personality, 28, 231-243. http://dx.doi.org/10.1002/per.1952

Lucas, R. E., \& Donnellan, M. B. (2011). Personality development across the life span: Longitudinal analyses with a national sample from Germany. Journal of Personality and Social Psychology, 101(4), 847-861. https://doi.org/10.1037/a0024298

Luciano, E. C., \& Orth, U. (2017). Transitions in romantic relationships and development of self-esteem. Journal of Personality and Social Psychology, 112, 307-328. http://dx.doi.org/10.1037/pspp0000109 
Lüdtke, O., Roberts, B. W., Trautwein, U., \& Nagy, G. (2011). A random walk down university avenue: Life paths, life events, and personality trait change at the transition to university life. Journal of Personality and Social Psychology, 101, 620-637. http://dx.doi.org/10.1037/a0023743

Mischel, W. (2004). Toward an integrative science of the person. Annual Review of Psychology, 55, 1-22. https://doi.org/10.1146/annurev.psych.55.042902.130709

Mueller, S., Wagner, J., Smith, J., Voelkle, M. C., \& Gerstorf, D. (2018). The interplay of personality and functional health in old and very old age: Dynamic within-person interrelations across up to 13 years. Journal of Personality and Social Psychology, 115, 1127-1147. https://doi.org/10.1037/pspp0000173

Mueller, S., Wagner, J., Hueluer, G., Hoppmann, C., Ram, N., \& Gerstorf, D. (2020). Moody and Thin-Skinned? The Interplay of Neuroticism and Momentary Affect in Older Romantic Couples. Manuscript resubmitted for publication.

Orth, U. (2018). The family environment in early childhood has a long-term effect on selfesteem: A longitudinal study from birth to age 27 years. Journal of Personality and Social Psychology, 114, 637-655. http://dx.doi.org/10.1037/pspp0000143

Plomin, R., DeFries, J. C., \& Loehlin, J. C. (1977). Genotype-environment interaction and correlation in the analysis of human behavior. Psychological Bulletin, 84, 309-322. https://doi.org/10.1037/0033-2909.84.2.309.

Rauthmann, J. F., Sherman, R. A., \& Funder, D. C. (2015). Principles of situation research: Towards a better understanding of psychological situations. European Journal of Personality, 29, 363-381. http://dx.doi.org/10.1002/per.1994

Roberts, B. W. (2009). Back to the Future: Personality and Assessment and Personality Development. Journal of Research in Personality, 43, 137-145. https://doi.org/10.1016/j.jrp.2008.12.015 
Scarr, S., \& McCartney, K. (1983). How people make their own environments: A theory of genotype $\rightarrow$ environment effects. Child Development, 54, 424-435. https://doi.org/10.2307/1129703.

Schwaba, T., \& Bleidorn, W. (2018). Personality trait development across the transition to retirement. Journal of Personality and Social Psychology, Advance online publication. http://dx.doi.org/10.1037/pspp0000179

Shah, S., McRae, A. F., Marioni, R. E., Harris, S. E., Gibson, J., Henders, A. K., ... Visscher, P. M. (2014). Genetic and environmental exposures constrain epigenetic drift over the human life course. Genome Research, 24, 1725-1733. http://dx.doi.org/10.1101/gr.176933.114

Soto, C. J. (2019). How Replicable Are Links Between Personality Traits and Consequential Life Outcomes? The Life Outcomes of Personality Replication Project. Psychological Science, 30(5), 711-727. https://doi.org/10.1177/0956797619831612

Wagner, J., Becker, M., Lüdtke, O., \& Trautwein, U. (2015). The first partnership experience and personality development: A propensity score matching study in young adulthood. Social Psychological and Personality Science, 6, 455-463.

http://dx.doi.org/10.1177/1948550614566092

Wagner, J., Lüdtke, O., \& Robitzsch, A. (2019). Does personality become more stable with age? Disentangling state and trait effects for the big five across the life span using local structural equation modeling. Journal of Personality and Social Psychology, 116(4), 666-680. https://doi.org/10.1037/pspp0000203

Wagner, J., \& Mueller, S. (2017). Personality development in late adulthood. In V. ZeiglerHill \& T. K. Shackelford (Eds.), Encyclopedia of Personality and Individual Differences. Springer International Publishing AG. 


\section{Recommended Readings}

Bleidorn, W., Hopwood, C. J., \& Lucas, R. E. (2018). (See References). A review on lifeevents and personality trait change research.

Briley, D. A., \& Livengood, J., \& Derringer, J. (2018). (See References). A good overview article on gene-environment interplay research.

Ge, X., Natsuaki, M. N., Neiderhiser, J. M., \& Reiss, D. (2009). (See References). An innovative study design to disentangle diverse sources on personality stability and change. Kandler, C., \& Ostendorf, F. (2016). (See References). A recent take on gene-environment interactions on depression.

Mueller, S., Wagner, J., Hueluer, G., Hoppmann, C., Ram, N., \& Gerstorf, D. (2020). (See References). An integration of experience sampling and longitudinal data on personality change in late life couples. 